\title{
Editorial
}

\section{Lloyd Owen}

U ppermost in the minds of many in this last quarter of 2001 has been the globally transmitted horror of the 11 September atrocity at the World Trade Centre in New York. What premium do we place on non-violent ways of doing things? What models and enduring images do we want to accentuate for our children? I suspect that most of us are capable of violence given sufficient frustration, ambition or a threat or cause in which we believe such action is justified. I suspect we have evolved in a way which renders us capable of doing great harm when we feel hurt enough to strike out or strike back or when we have sufficiently demonised another to act with the full force of our anger and the power at our disposal. The urgent task for us all both locally and globally is to develop and make accessible those forms of exercising power which protect the vulnerable and constrain the violence - a way based on respect, a belief in the need for restorative justice. Restorative justice is popular at present in those systems used to dealing with tough delinquent and offending behaviour. Its clear extension into policy making and popular communication is an urgent imperative. Bring on a strong system of international criminal and civil law and courts, we cannot do without them, we need much less recalcitrant and oppositional behaviour from bodies like the United States Congress and the Australian Government in matters which will help the United Nations and its Covenants and Conventions work to the advantage of the global citizen, rather than powerful partisan interests. The triple bottom line of economic, social and environmental responsibility which is often quoted by the present Victorian Government is a serious necessity beyond any partisan interest. Of course such objectives are not easy and both ends and means are not always clear as to form, and approaches are often legitimately tested. All the more reason to muster our best efforts around research and processes which will help us to better understand what works best in achieving safe and satisfying outcomes, individually and collectively on a daily basis and across our lifetime.

It has been heartening to meet with practitioners, researchers and representatives of agencies, young people, business and government in the context of the Face to Face process (see www.create.org.au). Recent months have seen the beginning of an effort to develop a National Research Agenda for the child and family welfare field. Frank Ainsworth and Judy

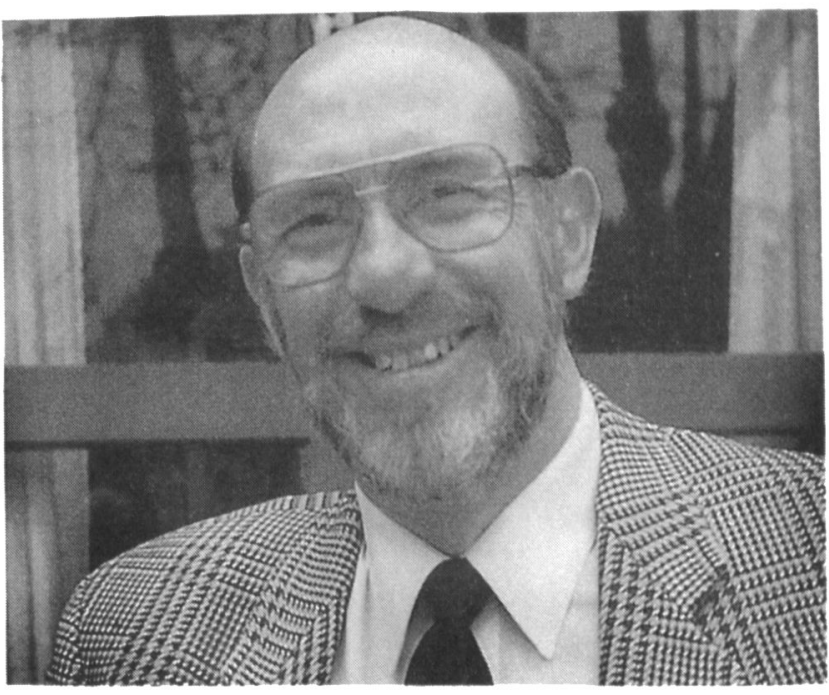

Cashmore have been instrumental in furthering these developments and I am sure they would be happy to hear from others with an interest. In the meantime it is positive to note the amount of activity which is occurring and the increasing amount of Australian research and literature relevant to the field which is appearing. Opportunities to participate in conferences, workshops and similar events are numerous and often, regrettably, in competition with each other. Often we are deadlined-out in the effort to put in a bid, give some feedback or just keep track of things. I suspect that the high tech era has added to the time pressure, rather than alleviated it, although it has clearly improved some of our capacity to conceptualise and to count. I hear from friends who did have time to listen to Robert Putnam on his recent visit that contemporary society is also filling much more of its time with work (if you have it), travel and TV, at the expense of other socially significant activities. That does ring a bell. The challenge is no less than it has ever been (and I suspect it may be more than at some other times in history) to create environments in which children can be heard, respected and valued as themselves, and can grow free of the distortions which grow adults who plan or permit calamitous events which destroy or displace life and its quality.

The theme of the recent $8^{\text {th }}$ Australasian Conference on Child Abuse and Neglect was 'One Child's Reality - Everyone's Responsibility'. Ample evidence was presented that the reality for many children is violence, exploitation or neglect. We can now look up the extent of many of these things on the web, eg, the UNICEF report, The State of the World's Children 2002 (www.unicef.org), and the Report Card on the Education of Australian Children and Young People in Care 2001 (www.create.org.au). Conference presentations indicate that many are working away at the tasks these situations generate. There was a sense though that on some fronts we have slipped behind and that on others our vision is blurred. There was concern that some of the internationally dominant ideologies are laissez faire on safety, justice and quality of life for too many people in too many places. Division, dominance, suspicion and marginalisation are prominent forces which need to be firmly challenged and addressed. Australia has a Government re-elected and now beginning a new term. Hopefully it will be informed by the best available 
knowledge in exercising its weighty responsibility in local and international affairs. The following articles in this issue of Children Australia point to much needing to be done.

Shurlee Swain, in the first of two articles exploring the history of child welfare in Australia and the writing of it (historiography), looks at salient themes from the attitudes, discourse and circumstances of the times in the six colonies and their successors, the States, from 1788 to 1939. This first article concentrates on welfare services for non-indigenous children. The second article to follow in the next issue of Children Australia will discuss post-war developments, the history of indigenous child welfare and the historiography of Australian child welfare. Much of what the field does and deals with now connects with and reflects its history. These articles add substantially to our understanding.

Two articles in this issue take up the theme of the participation of children and young people in the making of decisions which affect their lives. The issue is often raised and it is established as principle in the articles of the UN Convention on the Rights of the Child, but the extent to which it is put into effect has not been easy to see. In these articles, some Australian research has been identified which, in addition to being inclusive in its own right, draws attention to some of the means which might be used to embody such a principle in practice. Judy Cashmore and Andrew O'Brien, in their article 'Facilitating participation of children and young people in care', report on some legislative developments in Australian jurisdictions around the principle. They draw on a number of Australian studies and the wider literature to explore the nature and extent of participation in decision making in the care system, leading to a very useful checklist to be used by agencies and workers to evaluate this aspect of practice. Jan Mason and Robert Urquart, in their article 'Developing a model for participation by children in research on decision making', also take up the participation issue. They report on preliminary work in a three year ARC funded participatory research project involving children directly in developing a model of care better able to meet the needs of individual children. Along the way they share their thinking about three types of model which they identify as an adultist model, $a$ children's rights model and a children's movements model. We look forward to further developments in this collaborative project between UnitingCare Burnside and the University of Western Sydney.

The next two articles turn to a focus on families. First, Karen Healy and Gabrielle Meagher, in their article 'Practitioner perspectives on performance assessment in family support services', report the results of some focus groups involving family support practitioners which are the preliminary stage of a broader study of practice performance and ways of evaluating it. Their work has systematically included workers with and without professional qualifications, and within large and small organisations. There is a useful analysis of the nature of family support work, of the interest of practitioners in evaluating the worth of their work, and some indication of the strengths and shortcomings of present models of evaluation. Again these ideas will be helpful for the field, and the outcome of the broader survey is awaited with interest. Frank Ainsworth directs our attention to family preservation and family reunification services as he reviews research material from the United States and Britain, and the little there is from Australia. He points up the crisis in foster care which clearly forms part at least of the drive for current policy agendas which are trying to stem the tide of more children coming into care, and to increase and accelerate outlets. The renewed use of adoption and emerging evidence about the trend of overriding parental wishes are thoughtfully and forcefully raised. Are we creating a new stolen generation of infants while continuing to fail very needy older children and adolescents? This is just one of the questions raised by Frank's scholarly contribution. This article, 'Family preservation, family reunification and related issues: recent news', needs to be read by our politicians and policy makers. Beware of cheap and simplistic solutions to the needs of these vulnerable children and their families.

Our last but not least article in this late 2001 issue of Children Australia is from the South Australian researchers, Ken Rigby and Dale Bagshaw. 'What hurts? The reported consequences of negative interactions with peers among adolescent school children' boosts our thinking about the nature and significance of different forms of bullying. This work is probably ground breaking in terms of the conceptual extension of our thinking about these behaviours and their importance and differential nature and effects on boys and girls. There are lessons in this work for school management and much food for thought for those of us working with the young people whose status as bully and/or victim has become accentuated. The authors have also provided web site access to material of a 'what to do about it' nature.

Book reviews include Tom Keating's review of Mary Raftery and Eoin O'Sullivan's book, Suffer the Little Children, which provides a revealing historical account of the Irish system and, I think, lessons for us; and another review of a useful handbook for professionals in the area of parenting support.

Lloyd Owen 